
JNM
J Neurogastroenterol Motil, Vol. 22 No. 1 January, 2016
pISSN: 2093-0879 elSSN: 2093-0887
http://dx.doi.org/10.5056/jnm22011
(1) CrossMark
Journal of Neurogastroenterology and Motility
Corrigenda \& Errata

\title{
Corrigendum
}

\section{A Survey Using the Social Networks Revealed Poor Knowledge on Fecal Microbiota Transplantation}

Patricia Orduña, Sara Y Lopez, Max Schmulson, Rene Arredondo, Samuel Ponce de Leon, and Yolanda Lopez-Vidal

(J Neurogastroenterol Motil 2015;21:294-295; http://dx.doi.org/10.5056/jnm14146)

This article was initially published on the Journal of Neurogastroenterology and Motility with omission of a funding source. The funding source should be added as the following:

"Financial support: This work was supported by DGAPA PAPPIT UNAM (IV200315)." 